\title{
ENTRE A FORMAÇÃO, A EPISTEMOLOGIA E A POLÍTICA: A FILOSOFIA
}

O Vigésimo quarto número da RESAFE segue com a proposta de nossa revista em divulgar pesquisas que investiguem as diversas interfaces entre a educação $e$ a filosofia, buscando fortalecer as bases filosóficas da educação $e$ as bases educativas da filosofia. Nos doze anos que a RESAFE está em publicação, tem se esforçado para trazer perspectivas diversas que enfatizem estas interfaces, sem privilegiar caminhos específicos para que essas abordagens aconteçam.

Neste número encontraremos o texto de Adilbênia Machado que aborda o aporte da filosofia africana para a implementação do artigo 26-A da LDB através da perspectiva do encantamento e da ancestralidade, buscando espaços outros para o ensino da filosofia africana no cenário do próprio ensino da filosofia.

O texto de Darcísio Muraro investiga na obra de John Dewey a concepção de infância como crescimento, abordando potencialidades positivas disso que foi historicamente negativo em torno da imaturidade desta fase da vida. A noção de experiência é um marco importante desta investigação.

O pensamento filosófico do jovem Nietzsche é abordado no texto de Deniz Nicolay em sua leitura da extemporânea sobre Wagner em Bayreuth, buscando aí as concepções nietzscheanas de vida, arte e música e verificando de que modo estas noções impactam uma pedagogia do teatro trágico e expandindo suas consequências para o trabalho docente e a prática pedagógica.

A experiência do Fórum Sul de Coordenadores de Cursos de Filosofia e do Simpósio Sul-Brasileiro sobre o Ensino da Filosofia é abordada através da análise genealógica dos discursos, buscando identificar as condições de emergência dos discursos sobre ensino de filosofia na experiência destes dois movimentos na pesquisa conduzida por Elisete Tomazetti e Cláudia Benetti.

A concepção de natureza vistas desde a abordagem de Francis Bacon é investigada por Filipi Amorim e Humberto Calloni em seu artigo que abordam as dimensões éticas e epistemológicas das incidências teóricas do autor inglês e que se projetam em uma possibilidade de abordar a educação ambiental.

FLOR DO NASCIMENTO, wanderson. Entre a educação, a epistemologia e a política: a filosofia (Editorial). Revista Sul-Americana de Filosofia e Educação. Número 24: maio-out/2015, p. 1-2. 
Encontramos diálogos com Paulo Freire em dois artigos: o primeiro, na abordagem de Gildemarks Silva que busca as proximidades e divergências entre Freire e Illich no tocante às relações entre educação e transformação social $e$, no segundo, na leitura de Junot Matos e Adamo Medeiros que aborda, desde a "Pedagogia da Autonomia", a metodologia do ensino de Filosofia.

Neste número, encontramos também dois relatos de experiência: o primeiro trazido por Rita Andery e Sônia Siquelli e que nos conta acerca do trabalho com o programa "Educação para o Pensar" na Rede Pública de Educação de Piranguinho, Minas Gerais; o segundo, relatado por Samuel Schnorr, Carla Rodrigues e Josimara Schwantz, nos apresenta os ateliês de Escrileituras, buscando expor a escrita a $\mathrm{n}-1$, que explora um agenciamento rizomático dos saberes, a partir das filosofias da diferença.

$\mathrm{O}$ número se encerra com um dossier sobre as intersecções epistemológicas entre educação e formação, que traz dez textos que exploram em dimensões estéticas, políticas, pedagógicas, técnicas e éticas essas intersecções, por meio dos textos de Deborah Antunes, Filipe Ceppas, Isabella Ferreira (que, em parceria com Rosi Giordano, organizou o dossier), Paula Ramos, Raimundo Farias Júnior, Roberto Rondon, Roselaine Ripa, Rosi Giordano, Valmir Pereira e Walter Kohan.

Desejamos a todas $e$ todos uma excelente leitura $e$ seguimos na expectativa que bons encontros de leitura e pensamento marque a relação das pesquisas nas universidades e escolas e a RESAFE.

wanderson flor do nascimento

co-editor 